\title{
Randomness and Providence: Is God a Bowler or a Curler?
}

\author{
Kelly James Clark and Jeffrey Koperski
}

\subsection{How Does God Do It?}

Most Abrahamic theists affirm divine providence, the doctrine that God brings about or allows everything that happens in the universe; moreover, they hold that God controls creation so that all things either are good or work together for good.

How, then, does God do it? How does God's providential guidance work? These are old questions, but the traditional answers did not have to face the modern scientific claim that nature is, to some degree or other, random. How then can God ensure that God's providential aims are met? This is the central question of this volume. We briefly present some of the issues in this introduction.

K. J. Clark (两)

Department of Philosophy, Ibn Haldun University, Istanbul, Turkey

J. Koperski

Department of Philosophy, Saginaw Valley State University, University Center, MI, USA

e-mail: koperski@svsu.edu

(C) The Author(s) 2022

K. J. Clark, J. Koperski (eds.), Abrahamic Reflections on

Randomness and Providence, https://doi.org/10.1007/978-3-030-75797-7_1 


\subsection{The Bible Tells Me So}

The earliest Judeo-Christian view of creation represents God as creating the heavens and the earth and all they contain in six days. God created the heavens and the earth and then God populated the earth with plants, birds and sea animals, and land animals and humans on six successive days. Then God rested.

But God didn't rest for long. God, according to early folk science, routinely acts in the world or acts on the world to directly or indirectly create and sustain the heavens and the earth and all that they contain. Increasingly sophisticated views emerged starting in the first millennium $\mathrm{AD}$, allowing the doctrine of providence to comfortably evolve within a Greco-Roman framework for several centuries (Fergusson 2019, chap. 2).

\subsection{Modern SCIEnce}

The scientific and Darwinian revolutions would require Abrahamic theists to rethink God's activity in the world in at least two ways.

First, the discovery of the principle of inertia and the law of gravity would eliminate the need to postulate God's direct intervention or ultimate causation of the motion of the planets; as such, scientists would increasingly think of divine activity in the world as through God-created natural laws. God would not need to intervene in the natural order if events were already determined by the laws of nature, which God had ordained. A god that needed to tinker with nature from time to time, as Leibniz argued, would not be an omnipotent, omniscient creator (Leibniz and Clarke [1717] 1956, 11-12).

Second, the Darwinian revolution offered a compelling explanation for the development of plants, animals, and people in terms of natural selection. As such, scientists began to extend the notion of law into the biological realm. While one might think this a minor development, it was quite controversial at the time. It was commonly believed that while natural laws could explain the behavior of inorganic matter, they were in principle incapable of explaining the creation of plants, animals, and especially humans. While many religious scientists have increasingly come to understand God's creation in terms of God-ordained laws, many Abrahamic believers continue to believe that the origin of humans involves direct divine intervention. While such religious believers have easily accommodated the 
Newtonian world-picture for the planets and weather, they believe their Scripture forbids the extension of creation by natural law to, at least, people.

In sum, western religious scientists have increasingly come to believe that God creates and sustains the world - from planets to people-through the laws of nature rather than through direct divine intervention. Where, then, does divine providence fit in?

\subsection{Is God A Bowler or a Curler?}

Let's paint a word-picture, in the broadest strokes, to see how religious thinkers divide in their basic understandings of providence: is God a bowler or a curler?

In curling, the captain slides his heavy stone down the ice and then calls out instructions to his sweepers who direct the stone to its final destination. The captain does his best to set the stone on the right path, but it reaches its final destination only through the intervention of the sweepers. Typically, in curling, the stone couldn't reach its intended destination without the intervention of the sweepers.

In bowling, on the other hand, the bowler rolls her heavy ball toward the pins trusting its arrival at its final destination to both her initial throw and natural laws like gravity and friction. After her roll, she sits back and watches without any additional interference. Ideally, in bowling, the ball reaches its intended destination without the intervention of the bowler.

No one, of course, holds that God literally acts like a curler or bowler. However, one's rough view of divine providence-the way God operates in the world-tends to look like one or the other, bowler or curler. Whichever way one leans, what are the theological implications for one's view of divine creation and providence given the developments of modern science, including evolution by natural selection?

God as Curler If one holds that God is like a curler, one typically holds that God created the heavens and the earth in the beginning, and that God guides some events by direct divine intervention. According to the curler view, God might have directly created, say, plants and fish and mammals days, months, years, or even millions of years after God's initial creation. God, on this view, intervenes into the world to create either life itself or at least the conditions for the creation of say, plants and fish and mammals (and, of course, human beings). Among contemporary curlers 
are young earth creationists and intelligent design theorists-views in which God intervenes throughout history. According to young earth creationism, the earth and its contents were created six thousand to ten thousand years ago through an initial series of direct creative activities (over the course of, on the most famous view, six days); on some views the Earth itself has attained its present state through a subsequent series of God-directed catastrophes-like floods and earthquakes. The key point for our discussion: young earth creationists, rejecting evolution, attribute the creation of every kind of plant and animal to direct divine activity. Intelligent design theory holds that the origin of life and some complex features of living things are best explained by an intelligent, intervening cause (not an unguided or undirected process like natural selection). Since complex biological systems (such as blood-clotting or the flagellum of the Ecoli bacterium or the human eye) have features that, they claim, could not have arisen through evolutionary processes, an intelligent designer must have inserted itself at each point to create such complex processes. God, on the curler view, does not create everything through natural law; indeed, many Abrahamic theists believe that God creates the most important thingsincluding human beings - through direct, divine intervention.

God as Bowler If one holds that God is like a bowler, one holds that God creates by natural law. According to this view, God created the world perfectly in the beginning, including all the seeds of creation. While God creates everything in the beginning, including plants and fish and mammals, the plants and fish and mammals appear billions of years later through the operation of God-created natural laws. Contemporary theological bowlers tend to hold that evolution is the natural law through which God creates plants and fish and animals. One's view of the nature of God, the nature of God's creative activity, and the nature and integrity of God's creation determine one's views of how God creates: Does God create indirectly through natural law or directly through intervention? While these do not exhaust the options for divine action, proposals tend to lean one way or the other.

To be clear-both the bowler and the curler affirm that God creates and sustains the universe; moreover, both hold that God guides creation so that all things either are good or work together for good. But they disagree about how God is provident. 


\subsection{Randomness and Providence}

Science has complicated the picture. The bowler metaphor fit nicely with physics prior to the twentieth century. In classical mechanics, nature and its systems were machinelike, strictly governed by deterministic laws. Just as one could understand the regular behavior of a clock through observations and experiments, one could discover the underlying laws and mechanisms at work in nature. And with enough knowledge, physicists believed they could predict exactly how those systems would evolve over time. Indeed, according to Pierre-Simon Laplace ([1814] 1902), an intelligence with sufficient computational capacity could predict the future state of every particle in the universe.

What about random events, like throwing dice or flipping coins? From the point of view of classical physics, randomness is only superficial. If one knew exactly how the dice were thrown, what sort of surface they would land on, and so on, then one could calculate precisely how the dice will land. Dice-throwing and coin-flipping are "random" only in the sense that the average person doesn't have adequate information about either the conditions or the natural laws to make the calculations. But given the laws of nature, they must land precisely as they do. With few exceptions, socalled random events in classical mechanics are merely events that are too complex for humans to predict in real time. In reality though, their behavior is just as mechanical and deterministic as a clock.

That, however, is not the sort of universe we inhabit. After the discovery of quantum mechanics, we now know that nature is not mechanical and that classical physics does not describe how things work at subatomic scales. Parts of the quantum world are truly random; they are indeterministic and intrinsically unpredictable. Let's consider one example.

Materials like uranium undergo radioactive decay. In other words, uranium atoms are unstable-they will break apart given enough time. While we can predict how long it will take for some lump of radioactive material to decay, we can't predict which atom will decay or when. Suppose we zoom in and pick one specific uranium atom in the lump and ask, "When will this atom decay?" According to the standard interpretation of quantum mechanics, there is no precise answer to that question. A quantum physicist can tell you the probability that that atom will decay in the next hour or year or decade, but nothing more. Decay events are intrinsically random. There is no hidden mechanism that causes an atom to decay. Not 
even God could predict when such an event will happen based strictly on a complete knowledge of the laws of nature.

Notice what this means for God's providential control. In a quantum world, no matter how precisely God sets the conditions at creation, the universe will develop in an indeterministic way-that is, it will develop in ways that not even God could predict. If randomness were limited to radioactivity, there might be ways for God to deal with it. Unfortunately, this is just one example of an entire class of quantum events. The upshot is that God cannot bring about a particular outcome merely by setting the initial conditions of the universe. How, then, can God providentially guide events except by intervening?

As we've seen, evolution showed there are laws of nature governing the biological realm, but Darwinism presents a new set of problems for providence. While random mutations play an important role, "randomness" has a different meaning in biology than in physics. In biology, randomness primarily is the denial that evolution is guided by any sort of purpose.

According to Neo-Darwinism, genetic mutations do not occur for the benefit of a creature or species; mutations, as such, arise independently of the needs of a species. They are random in that a given mutation could be useful (adaptive) in acquiring food, resisting pests, finding a mate, and so on, but the mutation did not occur so that a species could acquire food, resist pests, or find a mate. Indeed, mutations are more likely to be useless or even harmful (that is, maladaptive). ("More likely" because it is easier for a mutation to undermine a useful trait than for it to produce an adaptive one.) Death and destruction, then, seem required for evolutionary "progress." Not only did the dinosaurs go extinct, it is estimated that $99.9 \%$ of all the species that have existed have gone extinct. It is difficult to see, then, how all things work together for good.

But randomness plays a significant role in evolution even apart from mutations. Small contingent events can have dramatic effects over time. Consider some possible scenarios:

A) A creature has a mutation that provides it with camouflage in its environment. This advantage will likely be passed on to future generations. But then a natural disaster changes the species' environment in such a way that the coloration instead makes it easier to be seen by predators. The traits that come to proliferate in that species will now be very different. 
B) A creature has a mutation that significantly improves its eyesight, but is eaten before it grows into an adult, thus preventing those genes from being passed on to later generations. As a result, a different species comes to dominate in that location.

C) The asteroid that struck the Yucatan peninsula 66 million years ago instead misses Earth entirely. The so-called Great Extinction, which changed the course of whole ecosystems, doesn't come to pass. As a result, pre-human mammals and, hence, humans never appear on earth.

The point is that there is a great deal of contingency in evolution. Chance, so it seems, plays the leading role in nature, not purpose, or design. Ecosystems are shaped by sudden changes to a local environment, or when otherwise favorable traits are selected out by a chomp, or by having/avoiding a natural disaster. While natural selection promotes-among other things - the survival of fittest, there is no guarantee that the fittest will survive and spread its genes within a given population. If mutations are random and their uptake in a species so radically dependent on countless contingencies, how could God guarantee the outcome of such a process?

Once all the randomness in the natural world is accounted for, one might wonder how one can believe in God at all, let alone God's providence. No surprise, then, that scientific randomness figures prominently in non-theistic worldviews. For example, biologist Douglas Futuyma claims that chance undermines belief in a creator: "By coupling undirected, purposeless variation to the blind, uncaring process of natural selection, Darwin made theological or spiritual explanations of the life processes superfluous" (1998, 5). And Harvard paleontologist George Gaylord Simpson asserts that "Man is the result of a purposeless and natural process that did not have him in mind" $(1967,345)$. Secular thinkers, who increasingly assert "chance" as a synonym for "naturalistic," allege that chance is by definition blind (thus, not divinely guided), and that chancy evolutionary processes preclude rational belief in God.

Any substantive claims about providence and randomness, on the part of believer and unbeliever alike, require serious, perhaps new, thinking about both providence and randomness. 


\subsection{Conclusion}

If one accepts both contemporary physics and biology, how can one reasonably maintain that God intentionally created the heavens and the earth and all that they contain?

This book is the result of a three-year, Templeton-funded project, involving 36 Muslim, Christian, and Jewish philosophers, theologians, historians, physicists, and biologists, aimed at understanding how the world can be as science tells us and God be as the Abrahamic scriptures tell us. In particular, how can God providentially and reliably guide creation if reality is random? Is it possible to be both scientifically and religiously faithful without loss to either?

\section{BiBLIOGRAPHY}

Fergusson, David. 2019. The Providence of God: A Polyphonic Approach, Current Issues in Theology 11. Cambridge: Cambridge University Press.

Futuyma, Douglas. 1998. Evolutionary Biology. 3rd ed. Sunderland: Sinauer Associates.

Laplace, Pierre Simon. (1814) 1902. A Philosophical Essay on Probabilities. Translated by F.W. Truscott and F.L. Emory. New York: Wiley.

Leibniz, Gottfried W., and Samuel Clarke. (1717) 1956. The Leibniz-Clarke Correspondence: Together with Extracts from Newton's Principia and Optics, ed. H.G. Alexander. Manchester: Manchester University Press.

Simpson, George. 1967. The Meaning of Evolution. Revised ed. New Haven: Yale University Press.

Open Access This chapter is licensed under the terms of the Creative Commons Attribution 4.0 International License (http://creativecommons.org/licenses/ by $/ 4.0 /$ ), which permits use, sharing, adaptation, distribution and reproduction in any medium or format, as long as you give appropriate credit to the original author(s) and the source, provide a link to the Creative Commons licence and indicate if changes were made.

The images or other third party material in this chapter are included in the chapter's Creative Commons licence, unless indicated otherwise in a credit line to the material. If material is not included in the chapter's Creative Commons licence and your intended use is not permitted by statutory regulation or exceeds the permitted use, you will need to obtain permission directly from the copyright holder.

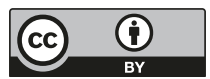

